\section{Sources of Potential Errors in the Application of Random Amplified Polymorphic DNAs in Cucumber}

\author{
Jack Staub ${ }^{1}$, Jeffery Bacher ${ }^{2}$, and Karl Poetter ${ }^{2}$ \\ Vegetable Crops Research, U.S. Department of Agriculture, Agricultural \\ Research Service, Horticulture Department, University of Wisconsin, Madison, \\ WI 53706
}

Additional index words. Cucumis sativus, cucumber, polymerase chain reaction, breeding, molecular markers, RAPD

\begin{abstract}
The influence of tissue age, pathogen infestation, intrapopulation contamination, and polymerase chain reaction (PCR) conditions were assessed as sources of error in random amplified polymorphic DNA (RAPD) analysis. DNA from young, uninfected tissue provided the most consistent results. Plants infected with Sphaerotheca fuliginea Schl. (ex Fr.) Poll. showed variation in RAPD banding patterns compared to those of uninfected plants. Differences in banding patterns were detectable when DNA from two inbred lines were mixed at dilution ratios of $\leq \mathbf{2 0 : 1}$ but not $\geq 50: 1$. Differing lots of commercially available $10 \times$ reaction buffer, $\mathrm{MgCl}_{2}$ stock solutions, and Taq DNA polymerase affected RAPD banding patterns and overall yield. For reproducibility of RAPD assays, it may be necessary to optimize reactions for specific lots of PCR reagents from either commercial or in-house sources.
\end{abstract}

Several types of molecular markers have been developed to assist in genetic analysis. One such marker, random amplified polymorphic DNA (RAPD) markers, is particularly well suited to high-through-put systems required for plant breeding because of the technique's simplicity, speed, and relatively low cost (Williams et al., 1990). RAPD methodology is useful in the construction of genetic maps (Kennard et al., 1994; Kesseli et al., 1994), tagging desirable traits for use in markerassisted selection (Martin et al., 1991, 1993; Michelmore et al., 1991; Paran et. al., 1991; Timmerman et al., 1994), and population and phylogenetic studies (Wilkes et al., 1993; Yu and Pauls, 1993).

Nevertheless, one potential problem with RAPD analysis is the technique's high sensitivity. Changes in tissue source, DNA extraction protocols, and PCR conditions can alter RAPD phenotypes, affecting reproducibility (Weeden et al., 1992). Because of the ability of PCR to amplify trace amounts of DNA, contamination also can be problematic in RAPD assays. Contamination can occur through errors in tissue sampling (intrapopulation contamination) or when plants are infected with microbial organisms. Characterization of the

Received for publication 9 Mar. 1995. Accepted for publication 25 Oct. 1995. Mention of a trade name, proprietary product, or specific equipment does not constitute a guarantee or warranty by the U.S. Dept. of Agriculture and does not imply its approval to the exclusion of other products that may be suitable. The cost of publishing this paper was defrayed in part by the payment of page charges. Under postal regulations, this paper therefore must be hereby marked advertisement solely to indicate this fact. ${ }^{1}$ Research Horticulturist and Professor.

${ }^{2}$ Research Associate. sensitivity of RAPD assays may aid in troubleshooting problems and increasing reproducibility of RAPD analysis. Given the necessity of reliable markers for genetic analysis, we investigated factors affecting RAPD banding patterns associated with 1) age of tissue sampled, 2) microbial and intrapopulation contamination, and 3) the use of different PCR reaction reagents.

\section{Materials and Methods}

DNA isolation. Standard CTAB phenol : chloroform extraction procedures were modified to optimize DNA quality and quantity in a mini-prep format (Maniatis et al., 1982). Frozen tissue ( 0.1 to $0.3 \mathrm{~g})$ was placed in a 2$\mathrm{ml}$ microcentrifuge tube along with two 4-mm stainless-steel ball bearings, chilled in liquid $\mathrm{N}$, vortexed for $15 \mathrm{sec}$, rechilled, and then vortexed for an additional $15 \mathrm{sec}$. About 750 $\mu 1 \mathrm{CTAB}$ buffer (CTAB, 2\%; $\mathrm{NaCl}, 1.4 \mathrm{M}$; EDTA, $20 \mathrm{~mm}$; tris, $0.1 \mathrm{M} ; 1 \% \mathrm{~B}$ mercaptoethanol) was added, vortexed for 30 $\mathrm{sec}$, then incubated for $1 \mathrm{~h}$ at $60 \mathrm{C}$. Subsequently, $750 \mu$ of 25 phenol : 24 chloroform : 1 isoamyl alcohol (by volume) was added, vortexed for $15 \mathrm{sec}$, and spun at $12,000 \mathrm{~g}$ for 5 $\min$. The upper phase was transferred to a new microcentrifuge tube, and $750 \mu \mathrm{l}$ of 24 chloroform : 1 isoamyl alcohol (v/v) was added, vortexed, and then spun at 12,000 $\mathrm{g}$ for $5 \mathrm{~min}$. The aqueous phase was transferred to a tube with $750 \mathrm{ml}$ isopropanol, incubated at room temperature for $10 \mathrm{~min}$, and spun at 12,000 $\mathrm{g}$ for $10 \mathrm{~min}$. The resulting pellet was washed with $70 \%$ ethanol, air-dried, and resuspended in $250 \mathrm{ml}$ of $10 \mathrm{~mm}$ tris $(\mathrm{pH} 8.0)$ and $0.1 \mathrm{~mm}$ EDTA, with 10 units of RNaseI (Promega, Madison, Wis.). The solution was incubated at $37 \mathrm{C}$ for $30 \mathrm{~min}$ and then stored at $-20 \mathrm{C}$.
RAPD assay. PCR amplifications were performed in $15-\mu 1$ reaction volumes containing $50 \mathrm{~mm} \mathrm{KCl}, 10 \mathrm{~mm}$ tris ( $\mathrm{pH} 9.0$ ), $0.1 \%$ triton X-100, 1.5 to $3.0 \mathrm{~mm} \mathrm{MgCl}_{2}, 200 \mathrm{~mm}$ each of dNTPs, 0.17 to $0.33 \mathrm{~mm} 10$-mer primer (Operon Technologies, Alameda, Calif.), 15 ng of genomic DNA, and 1 unit of Taq DNA polymerase. DNA was quantified by flourometry using a TKO 100 minifluorometer (Hoefer Scientific Supplies, San Francisco). PCR was performed in a thermocycler (model 9600; Perkin Elmer Cetus, Norwalk, Conn.) programmed for one cycle at $94 \mathrm{C} / 4 \mathrm{~min}$; three cycles at $94 \mathrm{C} / 15 \mathrm{sec}, 35 \mathrm{C} / 15 \mathrm{sec}, 72 \mathrm{C} / 75 \mathrm{sec}$ (ramp time $59 \mathrm{sec}$ ); 40 cycles at $94 \mathrm{C} / 15 \mathrm{sec}$, $40 \mathrm{C} / 15 \mathrm{sec}, 72 \mathrm{C} / 75 \mathrm{sec}$ (ramp time $59 \mathrm{sec}$ ); one cycle at $72 \mathrm{C} / 7 \mathrm{~min}$; and then $4 \mathrm{C}$ soak.

All RAPD reaction products were electrophoresed in $20 \times 25-\mathrm{cm}, 1.4 \%$ agarose gels with ethidium bromide at $0.5 \mu \mathrm{g} \cdot \mathrm{ml}^{-1}$ in $1 \times$ TAE buffer. Gels were run for $3 \mathrm{~h}$ at $96 \mathrm{~V}$ in gel apparatus (model BRL H4; Gibco, Bethesda, Md.), illuminated by ultraviolet light, and photographed with either Polaroid 667 film (Fabriqué au Royaume, U.K.) or with a still video system (Eagle Eye; Stratagene, LaJolla, Calif.).

Leaf maturity experiment. Seeds of cucumber lines G421 (R.L. Lower, Univ. of Wisconsin-Madison ) and H-19 (T. Morelock, Univ. of Arkansas-Fayetteville) were germinated in plastic pots $(13 \mathrm{~cm}$ in diameter; $700 \pm$ $50 \mathrm{ml}$ ) containing 1 sand : 1 compost soil : 1 peat (by volume). Cool-white fluorescent lights, providing $\approx 100 \mathrm{~mol} \cdot \mathrm{m}^{-2} \cdot \mathrm{s}^{-1}$ at shoot apex height, were used to extend the photoperiod to $16 \mathrm{~h}$ in a greenhouse that ranged from 17 to $28 \mathrm{C}$ during the growing period.

A split-plot design was used to compare sampling leaves at three nodal positions (nodes 2, 6, and 12 from the terminal whorl). Plots were arranged in a randomized complete-block design (RCBD) with two replications. Whole plots were inbred lines, and subplots were leaf sampling nodes.

Microbial experiment. Cucumber plants were infected with Erwinia tracheiphila [(E.F. Smith) Holland] (causal agent for bacterial wilt) or Sphaerotheca fuliginea (causal agent for powdery mildew) to determine the effect(s) of pathogen leaf infection on RAPD reactions. In each experiment, appropriate leaves from uninoculated greenhouse- and field-grown plants (Madison) were used as negative controls. Assays were performed with 20 Operon primers that previously had produced clear and repeatable banding patterns (Kennard et al., 1994). In experiments with each pathogen, plants were arranged in a RCBD with three replications and were rated by one person for severity of infection 4 to 6 days and 14 days after inoculation with $E$. tracheiphila and $S$. fuliginea, respectively. Plants infected with $E$. tracheiphila were rated as follows: $1=$ not infected, $2=$ slightly infected ( $1 \%$ to $<30 \%$ of the leaf wilted or showing visible lesions), $3=$ moderately infected (30\% to $<70 \%$ of the leaf wilted), or $4=$ severely infected $(\geq 70 \%$ of the leaf surface wilted). Plants inoculated with $S$. fuliginea were rated similarly, based on the relative frequency of visible surface lesions. 
Analyses of variance and mean separations of disease ratings were determined by WallerDuncan's K ratio $t$ test, where $\mathrm{K}=100$ (SAS Institute, 1992).

Erwinia tracheiphila was maintained in susceptible GY-14a cucumber line (R.L. Lower, Univ. of Wisconsin-Madison ) at 30C to stationary phase. Infected tissue $(\approx 0.8 \mathrm{~g})$ was ground using a mortar and pestle, and the sixth leaves of G421 and H-19 plants were inoculated by wounding with a flower frog (1 $\mathrm{cm}$ in diameter, 20 needles arranged in concentric rings) that had been dipped in inoculum (Abul-Hayja et al., 1975).

Since no axenic culture method is available for $S$. fuliginea, inoculum was maintained on leaves of 'Poinsett' cucumber plants through natural infection (Staub et al., 1989). Inoculum from severely infected leaves (white spore mass covering $\geq 80 \%$ of the leaf area) of maintainer plants was rubbed over plants to aid in pathogen inoculation of G421 and H-19 plants at the third leaf stage.

Intrapopulation contamination experiments. Experiments (two repetitions) that simulated contamination levels of one individual with tissue from a second individual were performed. Plant tissue was obtained from single plants, and RAPD analysis was performed under the conditions previously described.

The mixing experiment exploited two RAPD polymorphisms between cucumber lines PI 432860 (U.S. Dept. of Agriculture Regional Plant Introduction, Ames, Iowa) and GY-14a using the Operon N8 primer. DNA from the line not possessing the band $(\mathrm{P} 1=\mathrm{PI}$ 432860, 400 bp; P2 = GY-14a, 800 bp) was placed in many-fold excess to DNA from the line possessing the polymorphic band. Several dilutions were used and represented GY-14a : PI 432860 ratios of 1:1, 10:1, 20:1, 100:1, 1000:1, 10,000:1, and 20,000:1 and reciprocal dilutions (PI 432860:GY-14a). Similar studies were conducted using other RAPD primers.

$P C R$ reagent experiments. To test the effects of variation in PCR reagents on RAPD phenotypes, differing lots of $10 \times \mathrm{PCR}$ reaction buffer, Taq DNA polymerase, and $\mathrm{MgCl}_{2}$ stock solutions were substituted in otherwise identical RAPD assays. DNA extraction and PCR reaction conditions used were as previously noted.

For comparisons involving $10 \times$ reaction buffer, a single source of DNA (G421) was used in all assays in combinations with two primers (Operon C 10 and AT 1) and eight 10× reaction buffer lots from the same manufacturer. Each primer-buffer combination was tested twice. In the comparison of Taq DNA polymerase lots, DNA from parental lines (G421 and $\mathrm{H}-19)$ and $14 \mathrm{~F}_{2}$ progeny were tested with two lots of Taq DNA polymerase in combinations with three primers (Operon AK5, AE 1, and AD 17). A single source of DNA (G421) and primer (Operon AE 18) was assayed with four lots of $\mathrm{MgCl}_{2}(25 \mathrm{~mm}$ stock solution) diluted to a final concentration of 1.5 mM. The assay was repeated using the same DNA, primer source, and $\mathrm{MgCl}_{2}$ concentra- tions of $1.5,2.0,2.5$, and $3.0 \mathrm{~mm}$, with two replications for each concentration. The $\mathrm{MgCl}_{2}$ stock solutions were heated to $60 \mathrm{C}$ for $5 \mathrm{~min}$ then vortexed to redissolve any precipitate. Additional observations were made using reagents from other commercial sources.

\section{Results and Discussion}

Leaf maturity experiment. There were no visually detectable differences between lines in the RAPD banding intensities at any given node position in each experiment (data not presented). Likewise, RAPD banding patterns at any given node of a line were similar in each experiment (data not presented).

RAPD assays using older leaves (node 6 and below) exhibited visibly lighter and more inconsistent banding patterns than younger leaves (node 2) (Fig. 1). Reactions using progressively older tissue yielded progressively more unsatisfactory results (i.e., PCR products from DNA of the twelfth leaf were less visible than those of the sixth leaf). RAPD banding patterns from DNA of older tissue usually were not resolvable under conditions of this experiment (data not shown). This effect of tissue age on RAPD phenotype may be due to elevated amounts of degradative enzymes and polysaccharides present in older tissue (Baker et al., 1990; Lopez and Gomez, 1992; Murray and Thompson, 1980), which can alter DNA quantity and quality. Since DNA was extracted from samples having the same fresh weight, there may have been variation in the amount of DNA in tissues of different ages due to differences in cell size between expanding vs. mature leaf tissue.

Microbial experiment. Environment can affect the rate and severity of pathogen infection. Line G421 and H-19 are uniformly susceptible to S. fuliginea and E. tracheiphila under greenhouse conditions. Although differences in disease severity were detected between treatments (infected vs. uninfected control), no differences were detected between lines for a given treatment in each experiment (data not presented). Differences between replications were detected within each experiment. However, such position effects were random and inconsistent between experiments. Mean comparisons of infected plants within an experiment indicated that there were differences between plants in the severity of infection (data not presented).

Differences in RAPD banding patterns were detected between DNA samples extracted from leaves infected (moderately and severely) with

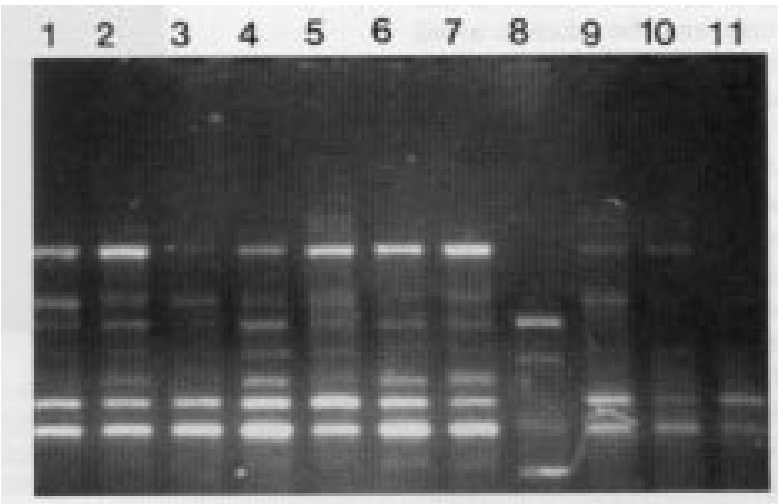

Fig. 1. Effects of leaf position and pathogen leaf infection on random amplified polymorphic DNA (RAPD) reaction integrity in cucumber. RAPD reactions using Operon G12 primer with DNA from line H-19 under standard thermocycler conditions. Lane: $1=$ node 6 leaf; $2=$ node 2 leaf; $3=$ node 12 leaf; $4=$ node 6 leaf, severe wilt; $5=$ node 6 leaf, slight wilt; $6=$ node 6 symptomless leaf from wilt-infected plant; 7 $=$ node 6 uninoculated field-grown leaf; $8=$ Erwinia tracheopila; $9=$ symptomless node 6 leaf from severely mildew-infected plant; $10=$ node 6 leaf, moderate mildew; and $11=$ node 6 leaf, severe mildew.

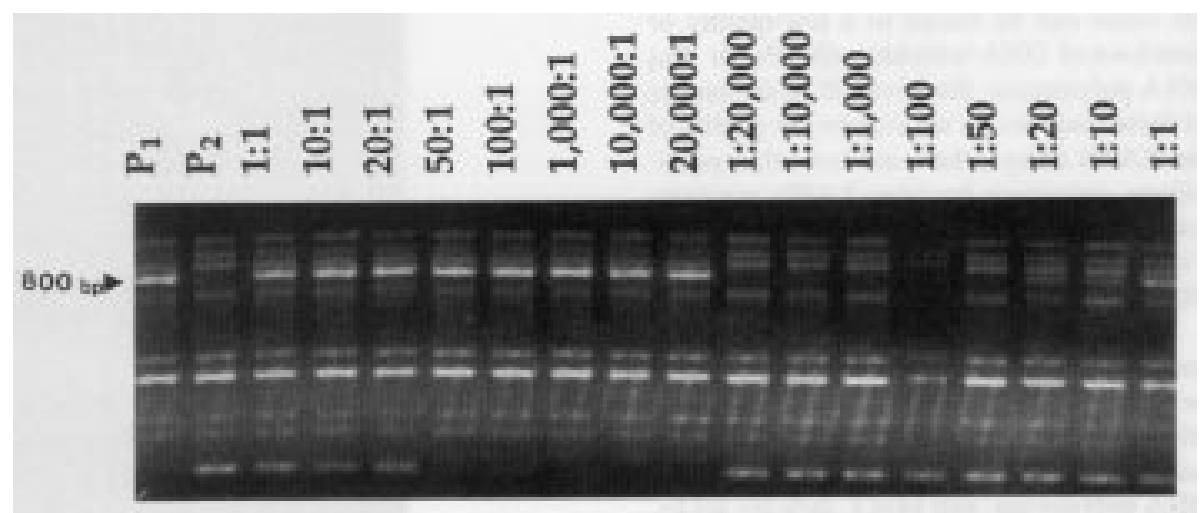

Fig. 2. Random amplified polymorphic DNA (RAPD) reactions of contamination reconstruction experiment using a total of $30 \mathrm{ng}$ cucumber DNA of lines PI $432860\left(\mathrm{P}_{1}\right)$ and G421 $\left(\mathrm{P}_{2}\right)$ and reciprocal $\left(\mathrm{P}_{2}: \mathrm{P}_{1}\right)$. Dilution ratios above each lane refer to ratio (in mass) of $\mathrm{P}_{1}$ DNA : $\mathrm{P}_{2}$ DNA. Arrows designate polymorphic bands and length is given in basepairs of Operon $\mathrm{N} 8$ primer products. 
S. fuliginea and uninfected (control) leaves (Fig. 1) (similar results observed with two other primers are not shown). Leaf infestation of $S$. fuliginea resulted in a decrease in the clarity of banding patterns more severe than nodal differences (lanes 9 and 10). In contrast, no appreciable differences in the presence and quality of bands were detected between DNA of leaf samples extracted from control plants (lane 7) and DNA taken from leaves infected with E. tracheiphila (lanes 4-6).

Powdery mildew is a common pathogen of field- and greenhouse-grown cucumbers. Clearly, if microbial contamination is suspected, appropriate controls must be included to avoid misinterpretation of results. The presence of this organism during DNA isolations could lead to reduced quality of RAPD through an alteration in the amount or quality of plant DNA.

Intrapopulation contamination experiments. No detectable polymorphic bands were observed at dilutions >50:1; however, contamination was clearly visible at dilutions of 20:1 in both experiments (Fig. 2). Although contamination was not detectable at low levels, the data do not imply that RAPD assays are completely unaffected by contamination. Similar results were obtained using other primers (data not presented). To obtain consistent and reliable results, care must be taken to avoid this source of error through careful adherence to good laboratory technique.

Sensitivity of RAPD assays to variation in $P C R$ reagents. Amplification conditions for RAPD assays determined by Williams et al. (1990) serve as a good starting point for optimization for a particular organism. However, these characteristics are in no way universal for all plant species and had to be modified for amplification of cucumber DNA using the thermocycler. Once a RAPD assay has been optimized for a specific organism and reproducible banding patterns and yields have been achieved, problems can still arise. A common occurrence in laboratories using RAPDs is that, for no apparent reason, the reactions will deteriorate or stop working altogether. The researcher then has to troubleshoot the cause of the reaction failure. Often, the RAPD assays will start to work again without the source of the problem ever being identified. Sometimes the cause can be traced to a low-quality or deteriorated DNA template, dNTPs, or Taq DNA polymerase. However, if fresh sources of these reagents do not restore the quality of the RAPD assays, there are few other possibilities remaining because RAPD reactions contain relatively few components (i.e., DNA, Taq polymerase, buffer, dNTPs, primer, and $\mathrm{MgCl}_{2}$ ).

These experiments indicate other possible sources of variation not commonly thought to be a problem in RAPD assays (Figs. 3-5). Differences in the quality of RAPD assays using various lots of $10 \times$ reaction buffer, Taq DNA polymerase, and $\mathrm{MgCl}_{2}$ indicate lot-tolot variation existed in the reagents tested. Although all reagents used had a single commercial origin, results indicate that chemical variation in commercial stock solutions can be a source of inconsistency in RAPD analysis. Reagents from other commercial sources have been used in our laboratory and occasionally similar observations were made regarding inconsistencies in PCR products, depending on the commercial source and reagents (lots) used (data not presented).

Minor changes in reaction buffer concentrations (up to two to three fold) do not significantly affect RAPD phenotypes (Weeden et al., 1992). However, we observed variation in RAPD phenotypes using differing lots of reaction buffer at the same concentration from the same manufacturer (Fig. 3). The quantity and quality of PCR product depended on the interaction between primer sequence and the source

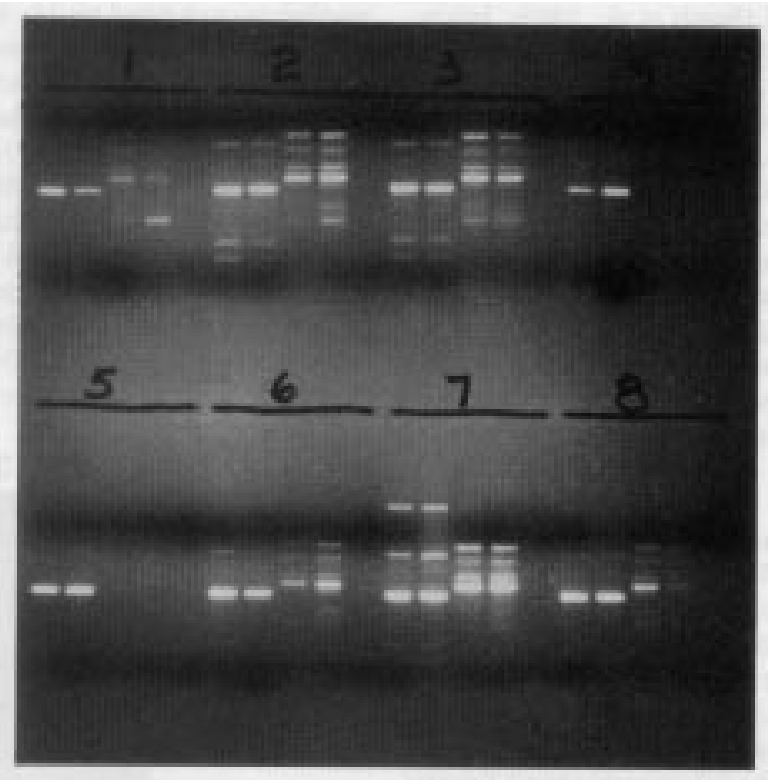

Fig. 3. Effects of variation in lots of $10 \times$ reaction buffer on random amplified polymorphic DNA (RAPD) assays. RAPD assays using eight lots of $10 \times$ reaction buffer, a single source of cucumber genomic DNA, and two 10-mer primers (Operon $\mathrm{H} 5$ in first and second lanes, and AK5 in third and fourth lanes of each buffer lot). Each primer-buffer combination was repeated twice.

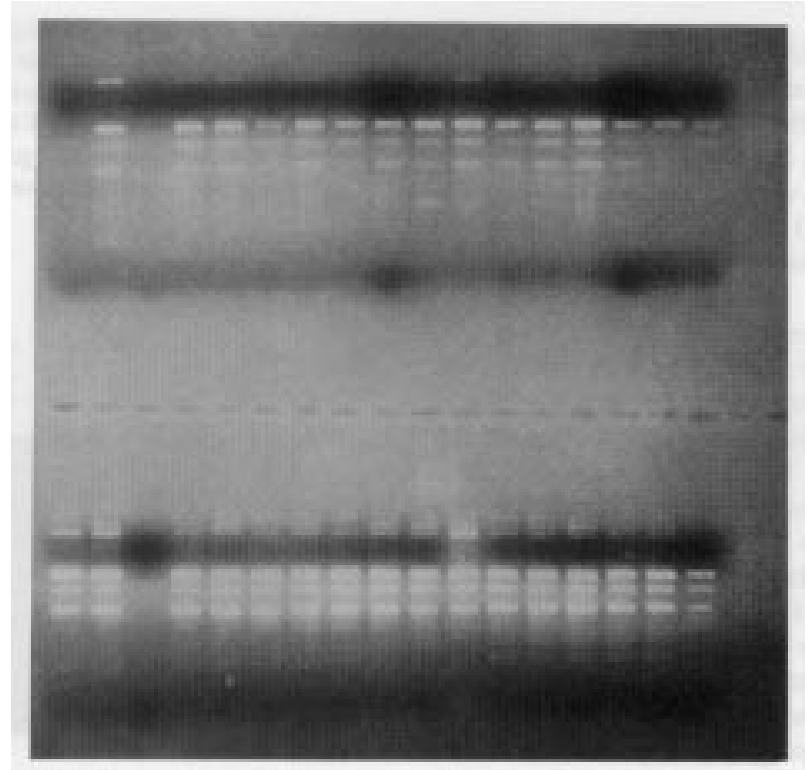

Fig. 4. Effects of variation in lots of Taq DNA polymerase on random amplified polymorphic DNA assays. DNA from parents G421 and $\mathrm{H}-19$ (lanes 1 and 2), control (i.e., no DNA; lane 3), and $14 \mathrm{~F}_{2}$ individuals tested with two lots of Taq DNA polymerase from the same manufacturer using Operon AK5 primer. 


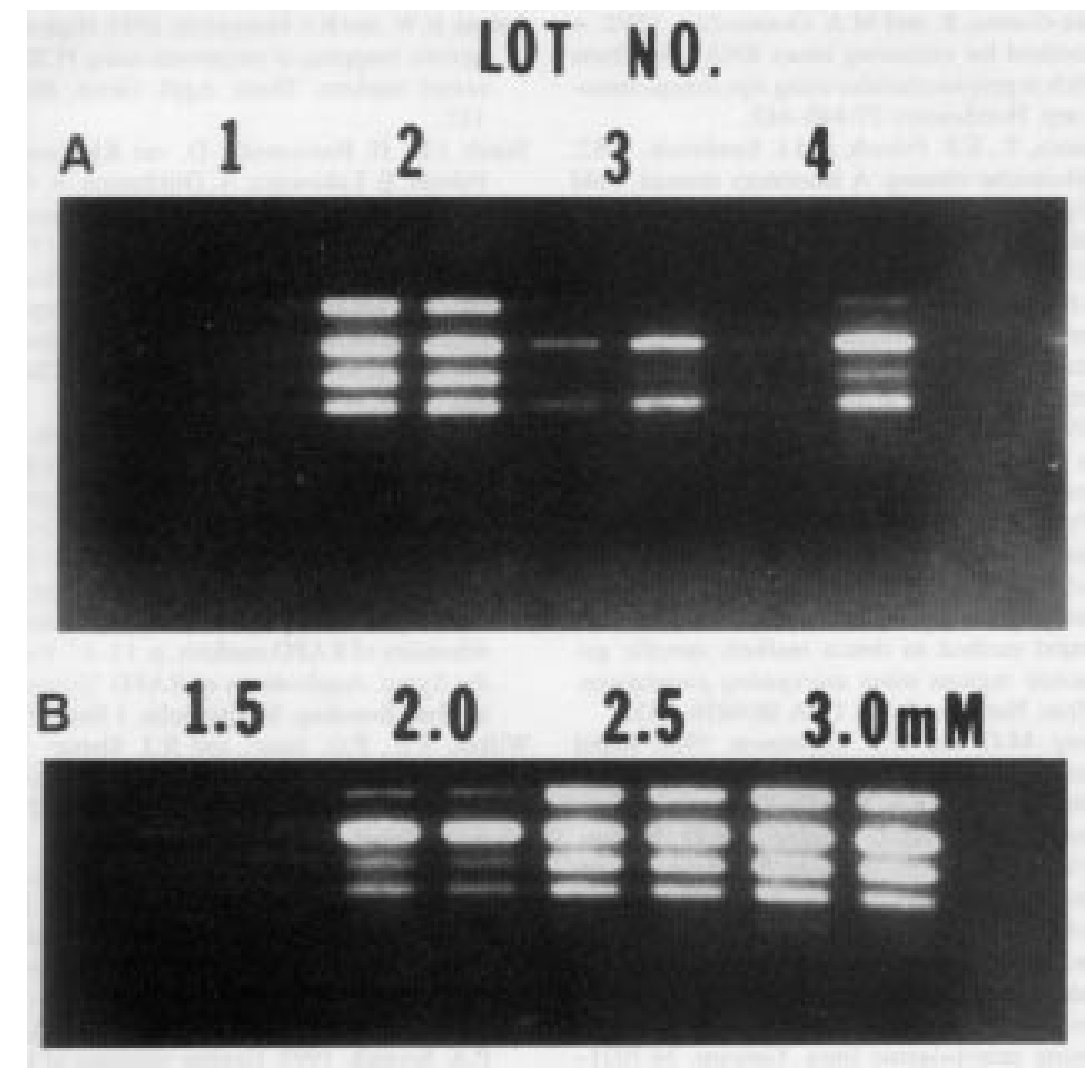

Fig. 5. Effects of variation between lots of commercially available $\mathrm{MgCl}_{2}$ stock solutions on random amplified polymorphic DNA (RAPD) assays. (A) A single source of DNA and primer (AE 18) were assayed with different lots of $\mathrm{MgCl}_{2}$ at $1.5 \mathrm{~mm}$ (two replications per lot number). (B) RAPD assays using the same genomic DNA and primer source with lot no. 1 of $\mathrm{MgCl}_{2}$ at 1.5, 2.0, 2.5, and $3.0 \mathrm{~mm}$ (two replications per concentration).

DNA polymerases from different manufacturers (i.e., Perkin-Elmer, Promega, and Boehringer). In contrast, our laboratory has experienced several cases of reduced RAPD assay quality resulting from the use of a particular lot of Taq DNA polymerase. Comparison between identical RAPD assays, except for the lot of Taq DNA polymerase used, revealed differences in RAPD phenotypes (Fig. 4) (similar results found with other primers not presented). Differences in RAPD assay quality existed between lots of Taq DNA polymerase, originating from other commercial sources, but to a far lesser degree (data not presented). Primer-dependent variation observed in comparisons of reaction buffer lots also was apparent with Taq DNA polymerase (data not presented).

Direct comparisons of the effects of differing lots of $\mathrm{MgCl}_{2}$ on RAPD assays revealed a wide range of yields (Fig. 5). The phenotypes varied from complete absence of any bands to normal banding patterns that occur under optimal conditions. In one case, where there were no visible PCR products, increasing the $\mathrm{MgCl}_{2}$ concentration from 1.5 to $2.5 \mathrm{~mm}$ restored the full RAPD phenotype. This result suggests that there was either some error in the manufacturer's stated molarity of the stock solutions or that modifications occurred that altered their effective concentration (e.g., precipitation during freezing and thawing) due to repeated use. Changes in $\mathrm{Mg}$ ion concentration $(>0.5 \mathrm{~mm})$ are known to affect the relative intensity of amplified bands (Williams et al., 1993); however, we had not expected to find variation between lots of a simple, singlecomponent stock solution. In our laboratory, it now is standard procedure to purchase $\mathrm{MgCl}_{2}$ in large lots and optimize the RAPD assay for that specific lot. Alternatively, in-house stock solutions could be made and aliquots tested and stored under appropriate conditions.

The presence or absence of RAPD marker phenotypes is due to either nucleotide substitutions or deletions in a primer binding site(s) or to changes in fragment size due to insertion or deletions within the amplified region (Williams et al., 1990). Any factors that alter the legitimate presence or absence of a RAPD band obviously can lead to misinterpretation of results. In this study, tissue age, contamination, and PCR reagents all were found to affect patterns.

Plant breeders often make late-season selections based on field performance. When the identification of target traits that are linked to molecular markers can only be made at or near plant maturity, DNA either must be extracted from older tissue of selected plants or the entire breeding population (often thousands of plants) must be sampled at an early stage of development. It is less work to select a few desirable phenotypes late in the season and examine the co-segregation of marker-trait associations in these selections. Results of this study, however, indicate that DNA extracted from older leaf tissue (12th node) produced bands with decreased intensity. A decrease in band intensity (i.e., faintness) can result in incorrectly scoring a RAPD band as absent.

Errors associated with the use and scoring of faint RAPD bands has been studied by Weeden et al. (1992). Eight times the number of double recombinants were found using faint compared to intense RAPD markers. This increase in the frequency of double recombinants is an indication of errors in scoring resulting from inconsistent amplification of a given band. About two-thirds of the errors were attributed to the absence of a legitimate band (presumably due to insufficient amplification), and about one-third were attributed to the presence of a bogus band (presumably due to contamination).

Errors in scoring of RAPD banding patterns can lead to misinterpretation of results. In mapping experiments, scoring errors can lead to increased map distances between adjacent markers, changes in marker order, and a decrease in confidence (i.e., lower likelihood odds ratio scores) in linkage predictions. In gene tagging, errors in scoring can result in identifying false linkages or overlooking real ones. Replicating analyses and using independently isolated DNA samples can help to minimize errors. Ultimately, segregation analysis with the appropriate populations is needed to confirm the genetic basis of linked markers as well as to determine genetic distances.

Conversion of RAPD markers to sequence tagged sites (STS) (Olson et al., 1989) or sequenced characterized amplified regions (SCARs) (Paran and Michelmore, 1993) by designing specific primers can help reduce problems associated with RAPD analysis. Those RAPDs that are unreliable should be considered for conversion to SCARs. However, conversion to SCARs is relatively expensive and time consuming, and not all RAPDs are converted easily. If a RAPD is closely linked $(<5 \mathrm{cM})$ to a desired trait and PCR conditions have been optimized to ensure high reproducibility, then SCARs development costs must be weighed against the risk of making errors in genotype identification using the RAPD analysis. Likewise, when PCR conditions have been optimized and the inheritance of RAPDs is known, then such markers can be used effectively for population studies, such as the assessment of genetic diversity. If a RAPD linkage map is available and SCARs with distinctly different characteristics (e.g., molecular weights) can be constructed from DNA in selected (equally spaced) genomic regions, then several SCARs might be used in one PCR reaction (multiplexing) to increase work efficiency. Nevertheless, the cost of SCARs development may be prohibitive, especially if the proposed use of the SCARs has limited scope (e.g., a one-time assessment of genetic diversity).

Genetic improvement projects are increasingly intended to improve gain from selection. Highly saturated maps that identify closely linked markers can increase breeding efficiency. Currently, we are merging maps constructed using different crosses and marker types (Kennard et al., 1994). The unified map 
will be more saturated than previous maps and, thereby, will increase the potential use of mapped RAPD markers for cucumber genetics and breeding.

Projects using marker-assisted breeding strategies require that small amounts of tissue be obtained from hundreds of individuals and that RAPD analysis of banding patterns be fast, simple, and inexpensive. Results of this study indicate that, in cucumber, RAPD assays are reliable and repeatable, providing that high-quality DNA is used, PCR conditions are monitored and optimized, and scoring is conservative (i.e., not using faint bands) to minimize errors. Although contamination of DNA through mixing or by pathogen infestation can result in altered RAPD banding patterns, such factors can be routinely controlled and, therefore, may have less consequence than spurious differences in commercial reagents.

\section{Literature Cited}

Abul-Hayja, F., P.H. Williams, and E.D.P. Whelan. 1975. Independence of scab and bacterial wilt resistance and ten seedling markers in cucumber. HortScience 10:423-424.

Baker, S.S., C.L. Rugh, and J.C. Kamalay. 1990. RNA and DNA isolation from recalcitrant plant tissues. Biotechniques 9:268-272.

Kennard, W.C., K. Poetter, A. Dijkhuizen, V.Meglic, J.E. Staub, and M.J. Havey. 1994. Linkages among RFLP, RAPD, isozyme, disease-resistance, and morphological markers in narrow and wide crosses of cucumber. Theor. Appl. Genet. 89:42-48.

Kesseli, R.V., I. Paran, and R.W. Michelmore. 1994. Analysis of a detailed genetic linkage map of Lactuca sativa (lettuce) constructed from RFLP and RAPD markers. Genetics 138:1435-1446.
Lopez-Gomez, R. and M.A. Gomez-Lim. 1992. A method for extracting intact RNA from fruits rich in polysaccharides using ripe mango mesocarp. HortScience 27:440-442.

Maniatis, T., E.F. Fritsch, and J. Sambrook. 1982. Molecular cloning: A laboratory manual. Cold Spring Harbor, Cold Spring Harbor, N.Y.

Martin, G.B., M.C. De Vicente, and S.D. Tanksley. 1993. High-resolution linkage analysis and physical characterization of the Pto bacterial resistance locus in tomato. Mol. Plant Microbiol. Intl. 6:26-34.

Martin, G.B., J.G.K. Williams, and S.D. Tanksley. 1991. Rapid identification of markers linked to a Pseudomonas resistance gene in tomato by using random primers and near-isogenic lines. Proc. Natl. Acad. Sci. USA 88:2336-2340.

Michelmore, R.W., I. Paran, and RV. Kesseli. 1991. Identification of markers linked to disease resistance genes by bulked segregant analysis: A rapid method to detect markers specific genomic regions using segregating populations. Proc. Natl. Acad. Sci. USA 88:9828-9832.

Murray, M.G. and W.F. Thompson. 1980. Rapid isolation of high molecular weight plant DNA. Nucleic Acids Res. 8:4321-4325.

Olson, M., L. Hood, C. Cantor, and D. Botsein. 1989. A common language for physical mapping of the human genome. Science 245:1434 1435.

Paran, I., R. Kesseli, and R. Michelmore. 1991. Identification of RFLP and RAPD markers linked to downy mildew resistance genes in lettuce using near-isogenic lines. Genome 34:10211027.

Paran, I. and R.W. Michelmore. 1993. Development of reliable PCR-based markers linked to downy mildew resistance genes in lettuce. Theor. Appl. Genet. 85:985-993.

SAS Institute. 1992. User's guide, release ed. 6.03. SAS Institute, Cary, N.C.
Sobral, B.W. and R.J. Honeycutt. 1993. High output genetic mapping of polyploids using PCR-generated markers. Theor. Appl. Genet. 86:105112.

Staub, J.E., H. Barcyznska, D. van Kleinwee, M. Palmer, E. Lakowska, A. Dijkhuizen, R. Clark, and C. Block. 1989. Evaluation of cucumber germplasm for six pathogens, p. 149-153. In: C.E. Thomas (ed.). Cucurbitaceae 89: Evaluation and enhancement of cucurbit germplasm. U.S. Dept. of Agriculture, Agricultural Research Service, U.S. Vegetable Laboratory, Charleston, S.C.

Timmerman, G.M., T.J. Frew, N.F. Weeden, A.L. Miller, and D.S. Goulden. 1994. Linkage analysis of er-1, a recessive Pisum sativum gene for resistance to powdery mildew fungus (Erysiphe pisi D.C.) Theor. Appl. Genet. 88:1050-1055.

Weeden, N.F., M. Timmerman, M. Hermmat, B.E. Kneen, and M.A. Lodhi. 1992. Inheritance and reliability of RAPD markers, p. 12-17. Proc. of the Symp. Applications of RAPD Technology to Plant Breeding. Minneapolis, 1 Nov. 1992.

Wilkes, S.E., P.G. Isaac, and R.J. Slatter. 1993. Random amplified polymorphic DNA (RAPD) markers for genetic analysis in Allium. Theor. Appl. Genet. 86:497-504.

Williams, J.G.K., A.R. Kubelik, K.J. Livak, J.A. Rafalski, and S.V. Tingey. 1990. DNA polymorphisms amplified by arbitrary primers are useful as genetic markers. Nucleic Acids Res. 18:6531-6535.

Williams, J.G.K., R.S. Reiter, R.M. Young, and P.A. Scolnik. 1993. Genetic mapping of mutations using phenotypic pools and mapped RAPD markers. Nucleic Acid Res. 21:2697-2702.

Yu, K. and K.P. Pauls. 1993. Rapid estimation of genetic relatedness among heterogeneous populations of alfalfa by random amplification of bulked genomic DNA samples. Theor. Appl. Genet. 86:788-794. 